UDC 547.29.02'26+621.892.099.6

\title{
ESTERS OF 1,1-BIS-(HYDROXYCARBONYLMETHYLTHIO) -1-PHENYLETHANE - ANTI-RUST ADDITIVES TO LUBRICATING OILS
}

\author{
S.F. Osmanova, S.A. Sardarova, F.A. Mamedov \\ Acad. A.M. Quliyev Institute of Additive Chemistry \\ National Academy of Sciences of Azerbaijan \\ AZ1029, Baku, Beyukshor highway, block 2062, e-mail: sabiya17@mail.ru
}

\begin{abstract}
Various 1,1-bis-(alkoxycarbonylmethylthio)-1-phenylethanes have been obtained through the esterification reaction of 1,1-bis-(hydroxycarbonylmethylthio)-1-phenylethane with diverse aliphatic alcohols. The compounds have been examined as additives to M-8 and M-12 oils.

It found that the synthesized compounds essentially improve anti-rust (protective) properties of oils. The best results go to 1,1-bis-(tridecyloxycarbonylmethylthio)-1-phenylethane which at a concentration of $1 \%$ excels by its anti-rust properties an urea succinimide additive (СИМ) taken as comparison standard.
\end{abstract}

Keywords: 1,1-bis-(hydroxycarbonylmethylthio)-1-phenylethane, esters, anti-rust additive, lubricating oils.

\section{INTRODUCTION}

The development of mechanical engineering and the toughening of requirements to the quality of lubricating oils have led to the expansion of works over creation and subsequent application of anti-rust (protective) additives in oils. Note that the need in anti-rust additives is also apparent at fuel pumping, longterm storage in tanks of cars or metal containers, as well as at essential watering, for example, on sea and river transport. Corrosive effect of fuels on metal leads to the pollution of fuels with corrosion products which worsen pumpability of fuels and their anti-wear properties.

Note that the material of pipelines, storage and fuel tanks also deteriorates from corrosion[1].

Anti-rust additives can be used in the oils applied in the regions with humid tropical climate, in coastal areas with high concentration of salt or corrosive gases in the air.
Protective effect of anti-rust additives lies in the formation on metallic surfaces of the protective film that prevents the impact on car components of organic acids contained in oils and formed by oxidation in the presence of humidity which get into oil in operation, as well as substances aggressive to some metals [2].

Currently, as anti-rust additives there are used АКОР-1Б [3], СИМ, СИАП, НГ-107, synthetic fatty acids and their esters and amides [4], petroleum and synthetic sulphonates, nitrated oils, urea succinimide, there is also known antirust additive based on the mixture of succinic anhydrides.

Despite intensive research work on the subject, there are still relevant issues of synthesis of new effective anti-rust additives, based on the available reagents. 


\section{EXPERIMENTAL PART}

Taking into account the above- their protective properties we examined mentioned and the continuing research work (investigated) esters of 1,1-bis[5,6] and believing that the combination of (hydroxycarbonylmethylthio)-1-phenylethane of sulfide sulfur with ester group could improve the following structure

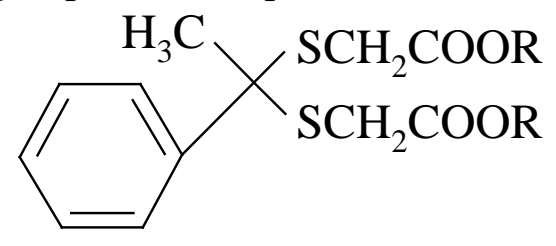

$\mathrm{R}=\mathrm{C}_{2} \mathrm{H}_{5}{ }^{-}, \mathrm{C}_{4} \mathrm{H}_{9}-, \mathrm{C}_{8} \mathrm{H}_{15^{-}}, \mathrm{C}_{13} \mathrm{H}_{27}$-which were synthesized as anti-rust additives to lubricating oils.

As oil there were used M-8 and M-12 motor oils.

Complex esters of 1,1-bis(hydroxycarbonylmethylthio)-1-phenylethane are easily dissolved in lubricating oils and cause no undesired changes in their physical and chemical properties.

Research was performed in accordance with ГОCТ 9.054-75 (State Standard) in different mediums: in a humidity chamber $(\Gamma-4)$ at high values of relative humidity; in the seawater ( $25 \%$ solution of sodium carbonate in distilled water) for 24 hours and under influence of hydrobromic acid for 4 hours. As a control, there were investigated oils without ester addition, as well as with СИМ (urea succinimide) additive taken as comparison standard. Results of the research are shown in table.

Table. Results of the research into 1,1-bis-(alkoxycarbonylmethylthio)-1-phenylethanes in M-8 and M-12 oils as anti-rust additives

\begin{tabular}{|l|l|c|c|c|c|}
\hline № & $\begin{array}{l}\text { Oil with additives of } \\
\text { the formula }\end{array}$ & $\begin{array}{c}\text { Concentration, } \\
\%\end{array}$ & $\begin{array}{c}\text { Corrosion, \% } \\
\text { chamber } \\
(\Gamma-4), \\
240 \text { hours }\end{array}$ & $\begin{array}{c}\text { Degree of } \\
\text { destruction in } \\
\text { electrolyte } \\
\text { solution } \\
\text { (method-4), } \\
\text { 24 hours }\end{array}$ & $\begin{array}{c}\text { Displacement of } \\
\mathrm{HBr} \\
\text { (method-5) } \\
\text { 4 hours }\end{array}$ \\
\hline 1 & $\begin{array}{l}\text { M-8 oil without } \\
\text { additive }\end{array}$ & - & 55 & 70 & 60 \\
\hline 2 & $\begin{array}{l}\text { M-12 oil without } \\
\text { additive }\end{array}$ & - & 60 & 80 & 50 \\
\hline 3 & $\begin{array}{l}\text { Sample without oil, } \\
\text { without additive }\end{array}$ & - & 100 & 100 & - \\
\hline 4 & $\begin{array}{l}\mathrm{M}-8 \text { oil with additive } \\
\left(\mathrm{R}=\mathrm{C}_{2} \mathrm{H}_{5}\right)\end{array}$ & 0.5 & 12.5 & - & - \\
\hline 5 & $\begin{array}{l}\mathrm{M}-8 \text { oil with additive } \\
\left(\mathrm{R}=\mathrm{C}_{8} \mathrm{H}_{15}\right)\end{array}$ & 0.5 & 8 & - & - \\
\hline 6 & $\begin{array}{l}\mathrm{M}-8 \text { oil with additive } \\
\left(\mathrm{R}=\mathrm{C}_{13} \mathrm{H}_{27}\right)\end{array}$ & 0.1 & 3 & - & - \\
\hline
\end{tabular}




\begin{tabular}{|l|l|c|c|c|c|}
\hline 7 & $\begin{array}{l}\mathrm{M}-8 \text { oil with additive } \\
\left(\mathrm{R}=\mathrm{C}_{13} \mathrm{H}_{27}\right)\end{array}$ & 1 & 0 & 1 \\
\hline 8 & $\begin{array}{l}\mathrm{M}-12 \text { oil with additive } \\
\left(\mathrm{R}=\mathrm{C}_{4} \mathrm{H}_{9}\right)\end{array}$ & 0.5 & 2 & 15 & 17.5 \\
\hline 9 & $\begin{array}{l}\mathrm{M}-12 \text { oil with additive } \\
\left(\mathrm{R}=\mathrm{C}_{13} \mathrm{H}_{27}\right)\end{array}$ & 0.5 & 3 & 5 & 22 \\
\hline 10 & СИМ (standard) & 1 & 6.5 & 7 & 6.5 \\
\hline
\end{tabular}

Table data show that the researched esters of 1,1-bis-(hydroxycarbonylmethylthio)1-phenylethane are notable for reasonably high level of indexes. Thus, indicators of oils in the absence of additives are worse by more than 10 15 times.

For example, when inserting tridecyl ester of 1,1-bis-(hydroxycarbonylmethylthio)-1phenylethane (compound 6) at a concentration of $0.5 \%$ into $\mathrm{M}-8$ oil, the corrosion of plates in the humidity chamber falls from $55 \%$ to $3 \%$, while its concentration growth up to $1 \%$ completely prevents the corrosion of plates both in the humidity chamber both in the presence of $\mathrm{HBr}$ acid but in the seawater it makes up just $1 \%$.

The best results in the humidity chamber among the examined samples in M-12 oil at a concentration of $0.5 \%$ fall on butyl ester of 1,1 bis-(hydroxycarbonylmethylthio)-1-

phenylethane, and in the seawater on tridecyl ester of 1,1-bis-(hydroxycarbonylmethylthio)-1phenylethane.

High efficiency of esters of 1,1-bis(hydroxycarbonylmethylthio)-1-phenylethanes, is obviously due to the presence of 2 fragments: -C-S-C- and 2 - COOR groups in the molecule. The combination of these fragments in the molecule of the compounds ensures the necessary level of protective properties of lubricating oils, both due to the sorption of esters on the surface of metal parts of the engine by the oxygen atom of the carbonyl group and the formation of a solid sulfide layer, as well as through the synergistic effects.

To sum up, the results of the tests go to show that the esters of 1,1-bis(hydroxycarbonylmethylthio)-1-phenylethane exhibit high protective properties and can be used as effective anti-rust additives to lubricating oils.

\section{REFERENCES}

1. Danilov A.M. Primenenie prisadok $v$ toplivah [Application of additives in fuels]. Handbook. Sankt-Peterburg : Himizdat Publ., 2010, 368 p. (In Russian).

2. Gnatchenko I.I., Borodin V.A., Repnikov V.R. Avtomobilnye masla, smazki i prisadki. [Motor oils, lubricants and additives]. Moscow: AST Publ., 2000, $268 \mathrm{p}$.

3. Puzevich N.L., Podchinok V.M., Shehter Ju.N. i dr. Zashhitnaja prisadka dlja prigotovlenija raboche-konservacionnogo masla [Protective additive for preparation of corrosion-preventing oil]. Patent RF no. 2136723, 1999.

4. Klimova T.A., Glinchak S.I., Kotin E.B. i dr. Prisadka $k$ uglevodorodnomu toplivu [Additive to hydrocarbon fuel]. Patent RF no. 2009174, 1994.

5. Sardarova S.A., Osmanova S.F., Mamedov F.A., Gamidova Sh.Y. Synthesis and research of 1,1-bis(hydroxycarbonylmethylthio)-arylethane 
esters. Kimya Problemleri - Chemical problems. 2015, no. 3, p.319-322 (In Azerbaijan).

6. Sardarova S.A., Osmanova S.F., Mamedov F.A., Abdullayev B.İ. 1,1-bis(hydroxycarbonylmethylthio)-1- arylethanes esters as multifunctional additives to lubricating oils. Azerbaijan Neft Teserrufati - Azerbaijan Oil Industry, Baku, 2016, no. 7-8, p. 46-48. (In Azerbaijan).

\section{1,1-BIS-(HIDROKSIKARBONILMETILTIO)-1-FENILETANIN MÜRӘKKӘB EFIRLORININ SÜRTKÜ YA ĞLARINA PASLANMAYA QARŞI AŞQAR KIMI TODQIQII}

\section{S.F. Osmanova, S.Ә. Sərdarova, F. Ә. Mommədov}

AMEA-nın akad. Ә.M. Quliyev adına Aşqarlar Kimyası Institutu AZ 1029, Bakl, Böyükşor şossesi, 2062-ci məh.; e-mail: sabiya17@mail.ru

1,1-bis-(hidroksikarbonilmetiltio)-1-feniletanin alifatik spirtlorlo eterifikasiya reaksiyası ilo müxtalif 1,1-bis-(alkoksikarbonilmetiltio)-1-feniletanlar alınmışdır. Sintez olunmuş birlaşmalar M-8 və M-12 sürtkü yağlarının paslanmaya qarşı (mühafizəedici) xassələrini nəzərə çarpacaq dərəcədə yaxşıllaşdırır.

Açar sözlor: 1,1-bis-(hidroksikarbonilmetiltio)-1-feniletan, mürəkkəb efirlər, paslanmaya qarşı aşqar, sürtkü yağları.

\section{ЭФИРЫ 1,1-БИС-(ГИДРОСИКАРБОНИЛМЕТИЛТИО)-1-ФЕНИЛЭТАНА - АНТИРЖАВЕЙНЫЕ ПРИСАДКИ К СМАЗОЧНЫМ МАСЛАМ}

\section{С.Ф. Османова, С.А. Сардарова, Ф.А. Мамедов}

Институт химии присадок им. акад. А. Кулиева Национальной АН Азербайджсана AZ 1029, г.Баку, Беюкшорское шоссе, квартал 2062; e-mail: sabiya17@mail.ru

Реакиией этерификации 1,1-бис-(гидроксикарбонилметилтио)-1-фенилэтана с алифатическими спиртами получены различные 1,1-бис-(алкоксикарбонилметилтио)-1фенилэтаны. Синтезированные соединения значительно улучшают антиржавейные (защитные) свойства смазочных масел $M-8$ и $M-12$.

Ключевые слова: 1,1-бис-(гидроксикарбонилметилтио)-1-фенилэтан, сложные эфиры, антиржавейная присадка, смазочные масла.

Received 11.06.2017. 